\title{
РОЗМОВНІ ІМЕННИКИ-КОМПОЗИТИ В СУЧАСНІЙ УКРАЇНСЬКІЙ МОВІ
}

Статтю присвячено тінгвістичному аналізові розмовних іменниківкомпозитів в украйнській мові кіния XX - початку XXI століття. Матеріалом для дослідження слугували переважно стилістично забарвлені одиниці (понад 100 слів), щзо функиіонують у розмовно-побутовому, публіиистичному та художньому стилях. Розглянуто джерела походження складних колоквіальних субстантивів, словотвірні моделі деривацї таких одиниць, їхню семантику, стильове й стилістичне використання. Уведено до наукового обігу значну кількість некодибікованих розмовних іменників-композитів.

Ключові слова: складні розмовні слова, композит, словотвірна модель, деривація, стилістичниц̆.

Styshov O. Colloquial Nouns-Composites in Modern Ukrainian Language. The article is devoted to the linguistic analysis of colloquial nouns-composites in Ukrainian language in the late 20th - early 21st century. The purpose of the study is to conduct the linguistic analysis of uncodified colloquial nouns-composites based on colloquial, publicistic and belles-lettres functional styles. The material for the study was mainly stylistically marked units (more than 100 words) which function in colloquial, publicistic and belles-lettres styles. Colloquial units are contrasted with stylistically neutral and bookish vocabulary. Their emergence and active functioning in modern Ukrainian language is primarily due to the public demand for the verbalization of the concepts and realities of our dynamic reality. The development of the analysed lexemes is caused by effective and influential tendencies in the national language - autochthonisation (or nationalization, ethnization), colloquialisation, anthropocentrism, saving lingual energy. The sources of origin of complex colloquial substantives, the main word-formation models of derivation of these units have been considered. It has been noticed that complex colloquial words predominantly have the same semantic content as free phrases or set expressions which they were derived from. However, there are those that have expanded their semantic volume in comparison with the basic word combination, received several meanings, and there are also units that are absolutely not motivated by the original word combinations. It has been evidenced that the studied words most intensively arise and dominate in the colloquial style, but now there is also a significant intensification of their use in publicistic and belles-lettres styles. The stylistic use of complex colloquial substantives has been analysed in sufficient detail. It has been evidenced that units with a negative-evaluative coloring predominate among the complex colloquial words. It is typical that they mainly work in intense colloquial dialogues and polylogues, quarrels, 
in political and pre-election discussions, feuilletons, humoresques, in character characteristics, on Internet blogs, forums, etc. On the concrete examples, it has been found that the mentioned lexemes often perform evaluative, image-creative, pragmatic and other functions. Complex colloquial units can express different stylistic registers: familiarity, playfulness, mockery, irony, disdain, vulgarity, swearing, etc. It has been revealed that the names of various persons dominate among the studied words, while the names of non-persons are relatively rare. A significant number of uncodified colloquial nouns- composites have been brought into scientific circulation.

Key words: complex colloquial words, composite, word-formation model, derivation, stylistic.

\section{Вступ}

У всіх живих мовах розмовна лексика була й залишається потужним джерелом поповнення їхнього словникового складу. Не становить винятку й сучасна українська мова. У ній тенденція до “орозмовлення” виявляється дуже зримо, особливо в кінці XX - на початку XXI століть. Названими одиницями в зазначену добу істотно поповнився не лише розмовно-побутовий стиль, а й публіцистичний та художній функціональні різновиди мови.

Різноманітні особливості розмовних слів постійно перебувають у полі зору як зарубіжних (М. Шанський, О. Земська, М. Костроміна, Л. Крисін, М. Ягубова, О. Мєшков, К. Вашакова, Г. Ядацка, Г. Марчанд та ін.), так і українських лінгвістів (В. Ващенко, М. Жовтобрюх, Д. Баранник, В. Русанівський, М. Пилинський, С. Єрмоленко, О. Тараненко, Л. Струганець, С. Бибик, Л. Шевченко, В. Грещук, А. Нелюба, М. Навальна, М. Лесюк, В. Христенок, Б. Коваленко, С. Головащук, Г. Віняр, Н. Босаківська, Н. Линник, Т. Кузнєцова, М. Скиба та багато ін.). Однак останнім часом в україністиці, на жаль, засвідчено мало грунтовних студій, присвячених вивченню складних розмовних одиниць. Знаходимо лише окремі роботи із зазначеної проблематики таких авторів, як Н. Клименко, О. Тараненко, Т. Левченко, І. МисливаБунько та ін. Тому вважаємо: ця тематика залишається досить важливо та на часі, що й визначає актуальність цієї статті. До того ж, складні розмовні іменники потребують фіксування, належного витлумачення і лексикографічного опрацювання.

Мета дослідження - лінгвістичний аналіз некодифікованих розмовних іменників-композитів на матеріалі розмовно-побутового, публіцистичного та художнього стилів. 
Досягнення поставленої мети передбачає розв'язання таких завдань: 1) увести до наукового обігу певну кількість не зафіксованих українськими словниками розмовних іменників-композитів; 2) виявити основні тенденції, що спричинили появу названих одиниць; 3) з'ясувати джерела походження розмовних іменників-композитів; 4) виявити продуктивні словотвірні моделі, за якими утворено колоквіальні складні слова; 5) проаналізувати семантичні, стильові й стилістичні особливості названих лексичних одиниць.

\section{Методи дослідження}

Методи та методики дослідження зумовлені специфікою вивчення матеріалу й метою його студіювання. Аналіз досліджуваних одиниць проведено за допомогою загальнонаукових методів - аналізу, синтезу, індукиї, дедукції. Використано низку лінгвістичних методів, зокрема такі: суцільної вибірки й описовий для виокремлення розмовних іменників-композитів, їх систематизації та аналізу; словотвірний аналіз застосовано під час дослідження словотвірних моделей складних колоквіальних субстантивів; компонентного аналізу, який дав змогу вивчити лексичну семантику зазначених одиниць, установити лексико-семантичні відношення; порівняльний метод, що сприяв осмисленню змін лексико-семантичної структури слів; дистрибутивний аналіз - з метою дослідження названих одиниць мови на основі оточення (розподілу) в тексті, а також частково була використана методика кількісних підрахунків.

\section{Виклад основного матеріалу}

Складні розмовні слова - цікавий фактичний матеріал із погляду походження, семантики, структурної організації та стильового й стилістичного використання. Аналізовані одиниці протиставляються стилістично нейтральній та книжній лексиці. Їх виникнення й активне функціонування в українській мові кінця XX - початку XXI століть спричинене передусім суспільним запитом для “ословлення” понять і реалій нашої динамічної дійсності.

Поява аналізованих лексем спричинена дієвою і впливовою тенденцією в сучасній українській мові до автохтонізації (або націоналізації, етнізації). Вона характеризується виникненням і розвитком або відродженням у національних мовах специфічних рис (питомих 
мовних явищ та одиниць), що засвідчують їхню відмінність від інших мов, оригінальність, неповторність. Це боротьба за збереження, відстоювання “національного Я”, а особливо творення нових слів з урахуванням структурних, семантичних, стилістичних та інших особливостей рідної мови й використанням усіх потенційних можливостей, закладених у ній, прагнення до повернення їй національної ідентичності й самобутності. Варто наголосити, що автохтонізація демонструє (поряд із іншими) менш потужну тенденцію до “орозмовлення”. Це істотне (порівняно з попередніми періодами розвитку національної мови) кількісне і якісне зростання розмовних слів та форм у розмовно-побутовому, художньому, публіцистичному й навіть зрідка в офіційно-діловому та науковому функціональних різновидах української мови.

Зібраний фактичний матеріал засвідчив, що 3-поміж складних розмовних слів переважають назви осіб або номени, пов'язані з людиною. Тобто розглядувані лексичні одиниці зумовлені ще однією важливою тенденцією в українській мові кінця XX - початку XXI століть - антропоцентризмом. Визнано, що однією з провідних тенденцій сучасної лінгвістики є вивчення “мови в людині” і “людини в мові” (Вокальчук, 2004: 9). Антропоцентризм ще визначають як вивчення мови з метою пізнання ії носія. На передній план виступають проблеми виявлення закономірностей лінгвосеміотичного засвоєння людиною навколишнього матеріального світу й інформаційного простору, стратегічної побудови спілкування для реалізації людських потреб, структурування вигідного для комунікантів середовища. Переконливими прикладами слугують колоквіальні складні слова, на зразок: скорогон 'той, хто дуже швидко їздить', гугломовець 'той, хто активно використовує пошуковий сервіс Google LLC', парохід 'студент, який справно відвідує заняття' та багато ін. Такі лексеми також є виявом тенденції до економії лінгвальної енергії.

Аналізовані слова характеризуються різним часом виникнення і генезою. Засвідчено як давні утворення (полоскозуб 'перший день Великого посту (понеділок), коли за традицією, випиваючи горілку, виполіскували скоромне'; горшкодеря 'той, хто любить добре поїсти, вишкрібаючи повністю страви з посуду'), так і нові одиниці (фейкомет 'масмедіа або інші джерела, які розповсюджують завідомо неправдиву інформацію'; кривосуддя 'несправедливий суд, судочинство’). 
Складні розмовні одиниці мають різні джерела походження. Зокрема, засвідчено: 1) власне розмовні, тобто виникли в живому народному мовленні: кровограй 'самогон', кобиздох 'жалюгідний, хворобливий собака'; 2) створені авторами під народну розмовність: швидкоїжка 'той, хто швидко поїдає страви', лицедурство 'спеціальна технологія, яка цілком правдоподібно зображує те, чого насправді не було' та ін. (Deepfake - технологія, заснована на штучному інтелекті, яка використовується для виробництва або зміни відеоконтенту, иілком правдоподібно зображує те, чого насправді не було. В Україні придумали власний переклад цьього терміна - "лицедурство", тобто щзось середнє між лицедієм-притворщиком і дурістю-легковажністю (газ. «Дзеркало тижня», 08.08.2019); 3) із соціальних діалектів, оскільки в останні роки засвідчено тенденцію до проникнення в розмовне мовлення слів із жаргонів (всесезонка 'автомобільні шини для будьякої пори року' (з автомобільного), москвобакс 'російський рубль' (із молодіжного), макодзьоб 'наркоман' (із наркоманського) та з арго (фуфлогон 'той, хто любить багато говорити, базікати', понтовод “той, хто вихваляється; ошуканець') та ін.; 4) запозичення або кальки (переважно з російської або англійської мови): семиділуха 'особа, яка одночасно робить кілька справ’ (пор. рос. семиделуха), дахолаз 'той, хто лазить по дахах або по висотних об’єктах’ (пор. англ. roofer від roof дах, покрівля).

Досліджувані колоквіальні одиниці мають переважно те саме семантичне наповнення, що й вільні або стійкі словосполучення, від яких вони утворені: водохльоб 'той, хто часто п'є (хлебче) воду', тобто внутрішня форма таких слів $€$ прозорою. Однак $€$ й такі, що розширили свій семантичний обсяг порівняно з базовими словосполученнями, набули кількох значень: кнопкода́в '1) депутат, який займається протизаконними діями, голосуючи на засіданні замість інших відсутніх осіб за їхньою згодою та / або дорученням; 2) той, хто постійно телефонує. Засвідчено й зовсім не мотивовані вихідними словосполученнями композити: кучмовоз 'великий ручний візок на двох або чотирьох колесах для перевезення сумок, баулів і т. ін.' Як бачимо, значення аналізованих складних слів більш містке, ніж в однокореневих лексемах, тобто вміщує певну кількість “семантичних тонів і обертонів” (як власне семантичних, так і конотативних), тобто вони характеризуються вищою глибиною змісту. 
Варто простежити також структурну організацію складних розмовних слів. Здебільшого це композити, утворені чистим основоскладанням (металокрадій 'той, хто краде метал', москвобакс 'російський рубль'), основоскладанням ускладненим суфіксацією (однозубка 'посадковий матеріал часнику одним зубком') та основоскладанням з усіченням (тискомір 'тонометр').

Зафіксовано кілька словотвірних моделей, за якими продукується більшість розмовних композитів. Засвідчено, що найбільш продуктивною $є$ модель на базі підрядного вільного словосполучення «іменник + опорне дієслово»: стінолаз 'той, хто лазить по стінах', грантоїд 'той, хто отримує гранти на певні проєкти (ринкові реформи, демократичні перетворення та ін.), створює видимість роботи, але гроші використовує здебільшого для власного збагачення'; жабоїд 'француз'; борщохльоб, зневажл. 'рот' та ін. Пор.: Пора якийсь канал організувати, заткнути без бухалова борщзольоби... (Є. Пашковський). За цією самою моделлю також активно продукуються іменники-композити на основі відомих фразеологічних сполучень як літературного, так і ненормативного характеру: водовар 'вередлива людина, яка мучить інших своїми причіпками, незадоволенням і т. ін.' (від ФО варити воду); соплежуй 'той, хто говорить нерозбірливо, нерішуче' (від ФО жувати соплі); понтоколот 'той, хто вихваляється, створює видимість чогось, говорить неправду' (від ФО понти колотити) та ін. Пор. у контексті: - Ох, як уже дістав нас ией понтоколот, який розійшовся у своєму репертуарі (з розм. мовлення). Менш продуктивною виступає модель на основі підрядного вільного словосполучення “іменник + опорне дієслово + суфікс -ець ": брендоносець 'той, хто носить брендовий одяг', білетоносещь 'народний депутат', мандатоносець 'те саме'. Напр.: - Не настільки важливо, брендоносець ти чи ні, важливо, що ти можеш поєднати речі для себе ${ }^{1}$. На нашу думку, певну роль у деривації названих слів відіграла також аналогія, зокрема такі кодифіковані лексеми, як: списоносец, рогоносець та ін. Малопродуктивною є модель «займенник + дієслово»: самокат 'саморобна горілка або підроблена кустарним способом', самоїд 'той, хто картає, допікає, сварить сам себе, не дає собі спокою', самосел'той, хто без офіційного дозволу влади, самовільно поселився

${ }^{1}$ Неделя в модой. Детектор медіа. 17.10.2009. Узято з https://detector.media/glamur-tuzhur/ article/146658/2009-10-17-nedelya-s-modoy/. 
в Чоробильській тридцятикілометровій зоні'. Пор.: Торік правоохорониі області прикрили діяльність тридияти шести гуралень, конфіскували тисячі тонн “самокату” (газ. «Україна молода», 03.02.2004, c. 7). Також засвідчено ще одну малопродуктивну словотвірну модель підрядного словосполучення «прикметник + опорний іменник»: синьоніс 'алкоголік', жирноморд 'той, хто має дуже повне обличчя'. Пор.: - А де подівся твій дружбан-жирноморд? (з розм. мовлення).

Засвідчено, що стильове використання таких одиниць обмежене трьома функціональними різновидами сучасної української мови. Закономірно аналізовані слова найбільш інтенсивно творяться і домінують у розмовно-побутовому стилі, а також нині помічено значну активізацію їх уживання в публіцистиці та красному письменстві. Пор. у контекстах: Нинішня хамовлада уже зовсім розпоясалася! (з розм. мовлення); Сьогодні ж на ТБ дуже часто поряд з суржикомовием присутня тише літературна російська мова! В такій ситуаціі у масовій свідомості виникає уявлення, що ией суржик - $і є$ украйнська мова, а правильна, гарна, повноцінна мова - ие російська (газ. «День», 20.11.2015); Але ці хлопи..., ия мужва..., иі штаноносіі... хіба їм треба розумної порядної жінки? Їм треба грочей, квартир, заможних тестів... (Г. Тарасюк).

Найбільшим розмаїттям характеризується стилістичне використання складних розмовних слів. Засвідчено, що з-поміж таких колоквіальних лексем істотно переважають одиниці з негативнооцінною маркованістю. Характерно, що здебільшого вони функціонують у наснажених розмовних діалогах і полілогах, сварках, у політичних та передвиборчих дискусіях, фейлетонах, гуморесках, у характеристиках персонажів, в інтернетних блогах, форумах тощо. Це можна пояснити впливом реалій сучасного життя з його неприхованою жорстокістю, зумовленою розгулом кримінальних і напівкримінальних структур, неправдою й ошуканством, реальними проблемами українців та повсякденними клопотами. Також спостерігаємо підігравання журналістів і письменників низьким смакам та вподобанням читачів, глядачів і слухачів.

Головна функція колоквіальних іменників-композитів, що мають яскраву внутрішню форму, оцінна - осуд, критика, викриття, розвінчання тощо: довбодятел 'дуже нерозумна людина; нікчема', носодер 'той, хто тримається гордовито, чваниться, зазнається' та ін. Пор.: 
- Ялюдина неконфліктна із такими довбодятлами, якви, не зв'язуюся ... (газ. «Україна молода», 20.04.2004, с. 16); А його колеги, mi, щзо вміють пити, уже давно «пішли вгору» і тепер з ним, із Славатієм Мурченком, навіть не вітаються, хоч половину із них повлаштовував на роботу саме він. - Усім записочки писав. Просив, благав. А тепер не вітаються. Носодери (О. Чорногуз).

Аналізовані лексеми неріко виконують образотворчу функцію: за допомогою таких слів автори дають влучну характеристику особам, та збуджують у респондентів певні образно-естетичні асоціації: кишкомот 'той, хто мучить, знесилює кого-небудь чимсь, набридає, нервує людей'; дурноляп 'той, хто говорить навмання, не подумавши'; парогуль 'студент, який прогулює заняття'; колорадоватник 'малоосвічений, люмпенізований і шовіністично налаштований росіянин або особа проросійської орієнтації, яка носять георгіївську стрічку і воює на Сході України проти української армії' та ін. Пор.: Просто колорадоватники злетілись, як мухи, писати різний непотріб 2 .

Складні розмовні іменники є важливим засобом творення експресивності й емоційності, часто виконують також прагматичні цілі - привернути увагу та вплинути на адресата інформації: бомжовоз 'транспортний засіб, що перевозить незаможні верстви населення'; грантожер 'особа, яка отримує гранти на певні проєкти (ринкові реформи, демократичні перетворення та ін.), створює видимість роботи, але гроші використовує в основному для власного збагачення'; діловар 'підприємлива, ділова людина'; зомбоящик 'телевізор' та ін. Пор.: Приміський електропоїз, елєктрічка, елєктрон, бомжовоз як тільки не називають ией транспорт (із соцмережі Instagram). Саме через це вони нерідко фігурують у заголовках: “Діловари” не втомлюються (заголовок статті) (газ. «Високий замок», 13.07.2004, с. 2); Російський “зомбоящци”": як захистити украйнський медіапростір від ворожої пропаганди (заголовок) (телеканал «5 канал», 22.07.2020).

Аналізовані одиниці можуть виражати різні стилістичні регістри: фамільярність (водохльоб 'той, хто часто п'є (хлебче) воду', губошльоп 'той, хто має великі відвислі губи'), жартівливість (кровограй 'самогон'), глузування (кнопкодав 'депутат, який під час голосування

${ }^{2}$ Розпорядженням міського голови перейменовано частину черкаських вулиць. Черкаси. Офіційний портал міської ради, міського голови, виконавчого комітету. 27.01.2016. Узято 3 http://chmr.gov.ua/ua/newsread.php?view=10742\&s=1\&s1=17\&s2=0\&commpage=2. 
натискає на кнопку й відсутнього колеги'), іронію (грошороб 'той, хто одержує певний зиск, накопичує кошти, отримуючи прибутки внаслідок певних дій, операцій, продажу, спекуляцій тощо', дуроящик 'телевізор'), зневагу (бидломаса 'значна кількість людей низького соціального й інтелектуального рівня'), стіномаз 'поганий маляр, який розписує стіни', соплежуй), вульгарність (задолиз 'підлабузник', жопосид 'той, хто досяг успіхів у навчанні, науці й т. ін. наполегливістю, настирністю, не маючи для цього великих здібностей і таланту'), лайливість (звіздобратія 'група людей, об’єднаних якимось негідним заняттям (злочинство, наркоманія тощо) або просто ледарів'). Такі колоквіальні композити нерідко творяться в живому народному мовленні відповідно до ситуації, образу, реалії. Зокрема, події останніх років, що відбуваються в Україні, відбиває нова лексема сепаробидло, утворене за допомогою слів сепар (розмовний варіант слова сепаратист) і бидло. Напр.: Що хоче сепаробидло? (з розм. мовлення).

\section{Висновки}

Отже, у кінці XX - на початку XXI століть лексико-семантична підсистема української мови під впливом екстра- й інтралінгвальних чинників істотно збагатилася шляхом активної деривації розмовних іменників-композитів. Такі складні колоквіальні субстантиви виступають надзвичайно важливим стилістичним засобом, виконуючи оцінну, образотворчу, емоційно-експресивну та інші функції.

У перспективі варто глибше дослідити такі одиниці в порівняльному аспекті, залучивши до аналізу інші слов’янські мови.

\section{ЛIТЕРАТУРА}

1. Вокальчук, Г. (2004). Авторський неологізм в украӥнській поезї XX століття (лексикографічний аспект). Рівне: Наук.-вид. центр «Перспектива».

\section{REFERENCES}

1. Vokalchuk, H. (2004). Avtorskyi neolohizm $v$ ukrainskii poezii XX stolittia (leksykohrafichnyi aspekt) [Autor's neologism in the Ukrainian poetry of the XX sentury (lexicographic aspect)]. Rivne: Nauk.-vyd. tsentr «Perspektyva».

Стишов Олександр Анатолійович - доктор філологічних наук, професор, професор кафедри української мови, Київський університет імені Бориса Грінченка; вул. Драгоманова, буд. 22, кв. 114, м. Київ, 02068, Україна. 
Tel.: +38-067-184-80-55

E-mail: styshov@ukr.net

https://orcid.org/0000-0001-6192-255X

Styshov Oleksandr Anatoliiovych - Doctor of Philological Sciences, Full Professor, Professor at the Department of Ukrainian Language, Borys Hrinchenko Kyiv University; 22 Drahomanova Str., Apt. 114, Kyiv, 02068, Ukraine.

Надійшла до редакції 15 березня 2021 року

\section{CITATION}

ДСТУ 8302:2015: Стишов О. А. Розмовні іменники-композити в сучасній українській мові. Лінгвістичні дослідження: зб. наук. пр. Харк. нац. пед. ун-ту імені Г. С. Сковороди. Харків, 2021. Вип. 54. Ч. II. С. 69-78. DOI: https://doi.org/10.34142/ 23127546.2021.54.2.07

AРA: Стишов, О. А. (2021). Розмовні іменники-композити в сучасній українській мові. Лінгвістичні дослідження, 54 (II), 69-78. DOI: https://doi.org/10.34142/ 23127546.2021.54.2.07 